\title{
Verticillium Wilt on Fiber Flax: Symptoms and Pathogen Development In Planta
}

\begin{abstract}
Adrien Blum, ${ }^{\dagger}$ UniLaSalle-Campus Rouen, Unité Aghyle, CS 40118, LaSalle Beauvais-Esitpa, 76134 Mont-Saint-Aignan Cedex, France; and Glycobiologie et Matrice Extracellulaire végétale EA 4358, SFR Végétal-Agronomie, Université de Rouen 76821 Mont-Saint-Aignan, France; Mélanie Bressan, UniLaSalle-Campus Rouen, Unité Aghyle, Abderrakib Zahid, Glycobiologie et Matrice Extracellulaire végétale EA 4358, SFR Végétal-Agronomie, Université de Rouen; and Département de Production, Protection et Biotechnologie végétale (Unité de Génétique, Biotechnologies et Amélioration des Plantes) Institut Agronomique et Vétérinaire Hassan II B.P. 6202 Rabat-Instituts, Madinat Al Irfan C.P. 10101, Morocco; Isabelle Trinsoutrot-Gattin, UniLaSalle-Campus Rouen, Unité Aghyle; Azeddine Driouich, Glycobiologie et Matrice Extracellulaire végétale EA 4358, SFR Végétal-Agronomie, Université de Rouen; and Karine Laval, UniLaSalle-Campus Rouen, Unité Aghyle
\end{abstract}

\begin{abstract}
Fiber flax (Linum usitatissimum L.), an important crop in Normandy (France), is increasingly affected by Verticillium wilt caused by the soilborne fungus Verticillium dahliae. This disease leads to nonnegligible yield losses and depreciated fibers that are consequently difficult to upgrade. Verticillium wilt is a major threat to a broad range of agriculture. In this study, susceptible fiber flax cultivar Adélie was infected by VdLu01 (isolated from fiber flax, this study) or green fluorescent protein-tagged VdLs17 (transformed and provided by the department of Plant Pathology, University of California, Davis). Between 3 and 4 weeks postinoculation, wilting symptoms on leaves were first observed, with acropetal growth during the following weeks. Pathogen development was tracked by confocal laser-scanning microscopy during the asymptomatic and symptomatic stages. First, conidia

germination led to the development of hyphae on root epidermis; more particularly, on the zone of cell differentiation and around emerging lateral roots, while the zone of cell division and the root tip were free of the pathogen. At 3 days postinoculation, the zone of cell differentiation and lateral roots were embedded into a fungal mass. Swelling structures such as appressoria were observed at 1 week postinoculation. At 2 weeks postinoculation and onward, the pathogen had colonized xylem vessels in roots, followed by the stem and, finally, leaves during the symptomatic stage. Additionally, observations of infected plants after retting in the field revealed microsclerotia embedded inside the bast fiber bundle, thus potentially contributing to weakening of fiber. All of these results provide a global account of $V$. dahliae development when infecting fiber flax.
\end{abstract}

Fiber flax (Linum usitatissimum L.) is an important source of fiber used for textile manufacture and composite materials (van Sumere 1992). Currently, France is the worldwide leader in fiber flax production, ahead of Belgium, Belarus, and the Russian federation (FAO 2016); more than half of this production is grown in the Normandy region (http://www.chambre-agriculture-normandie.fr/panoramalin-normandie/). Historically, most research on flax diseases has focused on Fusarium wilt (caused by Fusarium oxysporum f. sp. lini) and rust (caused by Melampsora lini), which have been the main limiting factors in flax production (Rashid 2003). However, among other harmful flax diseases, Verticillium wilt, a vascular disease caused by the soilborne fungus Verticillium dahliae Kleb. is becoming increasingly prevalent among fiber flax culture in France (Valade et al. 2015) (http://www.fiches.arvalis-infos.fr/).

Verticillium wilt is caused by species of the group Verticillium sensu stricto (Klosterman et al. 2009) and constitutes a major threat to a broad range of crops, leading to significant yield losses (Agrios 1997; Pegg and Brady 2002). Among the Verticillium spp., V. dahliae has the largest host range (Inderbitzin and Subbarao 2014) and the most significant economic impact, causing billion-dollar losses worldwide (Pegg and Brady 2002). The pathogen can form blackpigmented, multicellular resting structures called microsclerotia that can remain viable in the soil or in debris for 20 years (DeVay et al. 1974; Krikun and Bernier 1990; Wilhelm 1955). Verticillium wilt is difficult to control because of its inaccessibility during infection, long-term persistence in fields, broad host range, and scarcity of resistant plants. At present, no efficient solution exists, even if research

${ }^{\dagger}$ Corresponding author: Adrien Blum; E-mail: adrien.blum@unilasalle.fr

Funding: This work was supported by a "Région Haute Normandie" and FERDER grant.

Accepted for publication 11 May 2018.

(c) 2018 The American Phytopathological Society on varietal selection, agronomic methods, and antagonist microbes seems to be promising (Fradin and Thomma 2006; Klosterman et al. 2009; Yadeta and Thomma 2013). Several studies focused on race-specific resistance have highlighted an allelic form of $\mathrm{Vel}$, a gene encoding a cell-surface glycoprotein that leads to an incompatible reaction with $V$. dahliae race 1 pathotypes. $V$. dahliae race 1 strains are more aggressive than so-called race 2 strains on susceptible tomato cultivars (de Jonge et al. 2012; Diwan et al. 1999; Fradin et al. 2009; Grogan et al. 1979; Kawchuk et al. 2001; Rick et al. 1959; Schaible et al. 1951). To date, there is no fiber flax variety resistant to $V$. dahliae and no effective chemical control. In addition, the 6-to-7year interval between two flax cultures in crop rotation recommended to fight against soilborne diseases is limited because the inoculum is present for up to 20 years in soil and could have a broad host range. Therefore, an understanding of pathogen infection, colonization, and subsequent symptoms produced on fiber flax must be the first step toward innovative solutions against this disease.

On various plants, infection by $V$. dahliae occurs at the root surface level; fungal hyphae later invade xylem vessels and progress slowly in acropetal direction (i.e., from the bottom to top of the plant). Upon germination, each microsclerotium has the capacity to produce one to several infection hyphae, thus increasing the chance to engender a successful infection (Fitzell et al. 1980). However few of the infections lead to xylem colonization: Gerik and Huisman (1988) have estimated that $0.02 \%$ of root infections lead to systemic colonization in cotton. Similarly, when eggplant roots were inoculated with $V$. dahliae microsclerotia, only 1 of 205 infections led to systemic colonization (Bejarano-Alcázar et al. 1999). Recent studies of $V$. dahliae on different hosts were carried out by green fluorescent protein (GFP) transformed strains (inoculum of conidia) and confocal laser-scanning microscopy (CLSM), thereby providing substantial knowledge about the infection process on root and the colonization within the plant (Maruthachalam et al. 2013; Vallad and Subbarao 2008; Zhang et al. 2012; Zhao et al. 2014). According to these studies, germination of conidia on inoculated plants was generally fast; in less than $24 \mathrm{~h}$, one germ tube emerged from one or both ends of a conidium. Thereafter, the germinated conidia rapidly 
developed appressoria or evolved in a complex hyphal network that formed later appressoria between junctions of epidermal cells, points of entry for the further internal colonization (Vallad and Subbarao 2008). On Arabidopsis, spinach, or lettuce, hyphae growth followed the longitudinal axis of epidermal cells and was generally intercellular (Maruthachalam et al. 2013; Vallad and Subbarao 2008; Zhao et al. 2014). However, even if the infection occurs rapidly, the preferential root zones leading to a successful one vary according to the reports. For example, substantial colonization was limited to the tip of lateral roots and within the root elongation zone on lettuce (Vallad and Subbarao 2008). On Arabidopsis, only the root hair zone was colonized by germinated conidia (Zhao et al. 2014). In contrast, Zhang et al. (2012) observed that most of the conidia were on the meristematic and elongation zones of cotton roots but rarely on the root cap, and none were on the root hair. On spinach root, vascular colonization started from the root tip; in addition, a complex hyphal network leading to later infections was observed on the surface of the elongation zone (Maruthachalam et al. 2013). Internal colonization started within the elongation zone by entering the root cortical tissue intra- or intercellularly; subsequently, the pathogen hyphae reached the xylem vessels (Maruthachalam et al. 2013; Vallad and Subbarao 2008; Zhao et al. 2014). Once vascular colonization was established, the hyphae colonized neighboring vessels via pit pairs or perforation plates and pathogen development slowly extended to the lateral roots (Vallad and Subbarao 2008). The pathogen was either restricted to individual vessels (cotton or lettuce) or all of the xylem vessels were densely colonized (spinach). The hyphae progressed acropetally through root vessels toward the aboveground parts together with conidia production, accelerating the colonization by moving rapidly with the transpiration stream. Ultimately, the pathogen was also detected in the upper stem, inflorescence, and seed, leading to further contamination of the developing seedlings (Maruthachalam et al. 2013; Vallad and Subbarao 2008; Zhao et al. 2014).

Only a few scientific reports have dealt with Verticillium wilt on flax. Marchal (1940) reports wilting symptoms on plants and the presence of microsclerotia on roots in Belgium, Hoffmann and Rondomanski (1959) mention that Verticillium wilt is responsible for fiber that is brittle and consequently nonmarketable, and Fitt et al. (1992) describe Verticillium wilt symptoms and assess its occurrence and severity in some U.K. and German fields. According to the French monitoring organizations, symptoms on fiber flax related to Verticillium wilt have a metallic blue appearance on stems during retting (a process employing the action of microorganisms to separate fiber from the other parts of the plant) that become brittle and fragile, thus causing damage. The damage causes considerable yield losses and, consequently, depreciated fibers are difficult to upgrade. However, before retting, Verticillium wilt is hardly diagnosable because of possible confusion with water stress or Fusarium wilt (Valade et al. 2015) (http://www.fiches.arvalis-infos.fr/). On various plants affected with Verticillium wilt, necrotic lesions at the root cap or vascular discolorations within the root in advance of the pathogen colonization may be the first symptoms to be observed (Eastburn and Chang 1994; Vallad and Subbarao 2008; Vallad et al. 2006). Wilting of leaves is triggered a few weeks after inoculation, usually in the oldest shoots; wilting starts on one half of an infected leaf and slowly progress acropetally. Plants affected with Verticillium wilt are usually stunted and their vascular tissues show characteristic brownish discoloration. Defoliation, gradual wilting and death of successive branches, or the abrupt collapse and death of the entire plant may all be consequences of Verticillium wilt (Agrios 2005). However, the consequences of a Verticillium infection can differ between hosts; there are no unique symptoms that exist in all plants (Fradin and Thomma 2006). For example, infection on tomato triggers yellowing, and necrosis of the tips and edges of lower leaves, causing typical V-shaped lesions. In some cases, the veins may turn purple or brown, and yellow blotches may appear on leaves that later become necrotic and brown (Fradin and Thomma 2006). Wilt symptoms on spinach first affect the bolting stem, then inflorescence, including bracts that develop a chlorosis and flaccid aspect (Maruthachalam et al. 2013). On lettuce, Verticillium wilt symptoms first consist of angular chlorosis regions on leaves that become flaccid, then evolve into angular areas of necrosis (Pegg and Brady 2002; Vallad et al. 2006).

Considering that the symptoms and the resulting damage are unique in each host plant $-V$. dahliae interaction and the lack of reports on Verticillium wilt on fiber flax, we provide a complete description of observed symptoms and pathogen development, including spatial and temporal pathogen progress on the root, stem, and leaf, as monitored by CLSM.

\section{Materials and Methods}

Plant material. Fiber flax seed (L. usitatissimum 'Adélie') were provided by the cooperative Terre de Lin (Saint-Pierre-le-Vigier, France). Seed were sterilized by immersion in $70 \%$ ethanol for $2 \mathrm{~min}$, rinsed in sterile water for $5 \mathrm{~min}$, immersed in sodium hypochlorite $2.6 \%$ ( $\mathrm{vol} / \mathrm{vol}$ ) for $10 \mathrm{~min}$, and finally rinsed three times in sterile water before sowing. In July 2014, a 12.5-ha fiber flax plot (L. usitatissimum 'Aretha') was investigated in La Haye Aubrée, France (49 $39^{\circ}$ $73.0^{\prime \prime} \mathrm{N}, 0^{\circ} 67^{\prime} 50.1^{\prime \prime} \mathrm{E}$ ) approximately 3 months after planting (capsule stage). Within the plot, an infectious site containing wilting plants was clearly visible and, thus, susceptible to be affected by Verticillium wilt. Twenty samples of infected plants (C1 to C20) and 20 of noninfected plants were collected. Samples of flax straws, brittle or not, were collected in September 2014 (post retting) from the same plot.

Pathogen strains. V. dahliae strain VdLu01 was previously sampled from straw of diseased fiber flax during retting in August 2005 in Gueures (Upper Normandy, France) by Terre de Lin. This strain has the capacity to produce enough inoculum for an experimental assay. The Department of Plant Pathology (University of California, Davis) provided $V$. dahliae strains VdLs16 and VdLs17, isolated on lettuce and previously described as race 1 and race 2, respectively (Vallad et al. 2006), both of which were transformed with the GFP gene. Fluorescence was checked using an epifluorescent microscope (DM1000; Leica, Ketzlar, Germany) fitted with a 50-W Hg lamp (Leica). To obtain pathogen inoculum, each strain was grown in potato dextrose broth (PDB; $26.5 \mathrm{~g} \mathrm{liter}^{-1}$ ) with sterile water in a 500-ml Erlenmeyer flask, and placed on an agitator (150 rpm) for 15 days at $20^{\circ} \mathrm{C}$ in the dark. Conidia were subsequently isolated in phosphatebuffered saline (PBS) by crushing fungal masses on a $100-\mu \mathrm{m}$-pore sieve. Recovered conidia were counted on a Malassez cell and adjusted to $10^{6}$ conidia/ml before inoculation. Microsclerotia were obtained by using malt extract (MA; $10 \mathrm{~g} \mathrm{liter}^{-1}$ ) with sterile water in a 500-ml Erlenmeyer flask for 1 month at $20^{\circ} \mathrm{C}$ in the dark.

Inoculation procedure and plant cultivation. Two systems, a hydroponic/root-dipping method and a peat system/soil-drench method, were used for plant cultivation and inoculation. In both systems, plants were inoculated with VdLu01 and VdLs17 at a concentration of $10^{6}$ conidia $/ \mathrm{ml}$. All experiments were performed in a growth chamber at $23^{\circ} \mathrm{C}$, with a photoperiod of $16 \mathrm{~h}$ of light and $8 \mathrm{~h}$ of darkness. The hydroponic/root-dipping method was used for symptomatic observations and CLSM analysis (roots and aboveground parts). Sterilized seed were sown in sterile Murashige and Skoog medium $\left(4.3 \mathrm{~g} \mathrm{liter}^{-1}\right)$ solidified with agar $\left(15 \mathrm{~g} \mathrm{liter}^{-1}\right)$. Tenday-old seedlings were gently sampled. Roots were immersed for $1 \mathrm{~h}$ in a conidia solution or in PBS as a control. The root seedlings were subsequently transferred into sterile hydroponic Hoagland medium (Hoagland and Arnon 1950). The peat system/soil-drench method was used for symptomatic observations and CLSM analysis (aboveground parts). Sterilized seed were sown in Jiffy-7 pots (Jiffy Products International BV, Moerdijk, The Netherlands) with 1 seed/ pot. The bottoms of the Jiffy pots containing 10-day-old seedlings were drenched for $1 \mathrm{~h}$ with conidia solution or with PBS for controls. Jiffy pots were next transplanted into larger peat pots and plant stakes were set up after 3 weeks.

Light microscopy. Plant symptoms were imaged on a digital microscope (VHX-5000; Keyence, Osaka, Japan) with VH-Z20R and VH-Z100R (fitted with an OP-72405 polarization illumination attachment) objectives (Keyence), and $V$. dahliae fungal structures were imaged on a transmitted light microscope (DM1000; Leica) with $\times 10$ and $\times 100$ objectives at UniLaSalle (Mont-Saint-Aignan, France). 
Fresh and fixed samples in methanol, according to Zelko et al. (2012), were observed. Cross-sections of stems and roots were hand-cut under a binocular microscope, then mounted on a glass slide with glycerol $80 \%$ (vol/vol). Lactophenol blue solution (Sigma-Aldrich, St. Louis) was used to stain fungal structure. Briefly, mycelium was stained 5 min on a glass slide, then rinsed with distilled water before observation.

CLSM. Samples were fixed in methanol and then stored at $4{ }^{\circ} \mathrm{C}$ as described by Zelko et al. (2012) for further analyses. Root
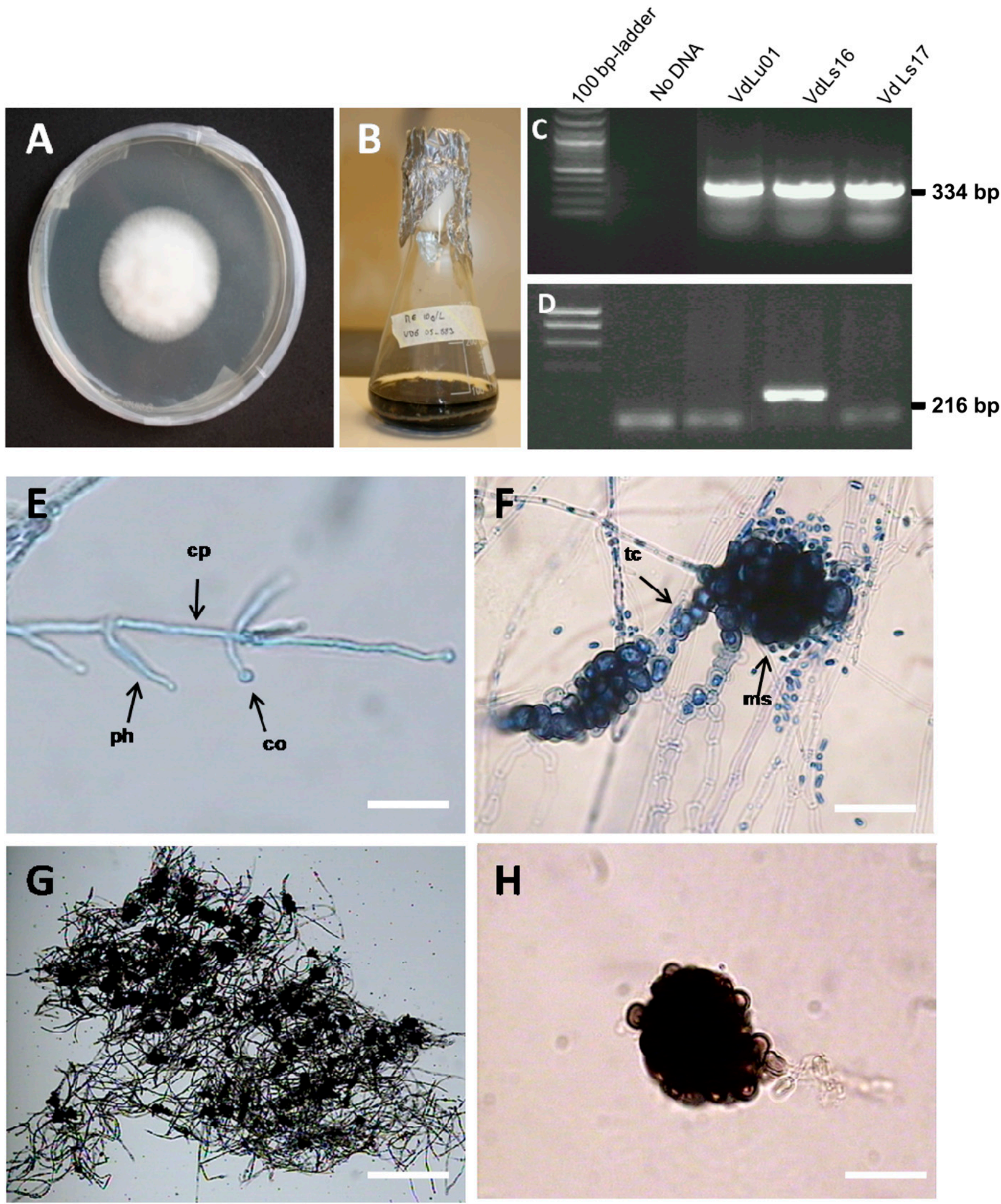

Fig. 1. Identification of VdLu01, a Verticillium dahliae strain isolated on fiber flax straw. $\mathbf{A}$ and $\mathbf{B}, \mathbf{E}$ to $\mathbf{H}$, morphological and $\mathbf{C}$ and $\mathbf{D}$, molecular traits. Macroscopic aspect of $\mathrm{VdLu} 01$ after growing $\mathbf{A}, 1$ week on potato dextrose broth agar medium and $\mathbf{B}, 1$ month on malt extract liquid medium. Polymerase chain reaction amplification using primers targeting $\mathbf{C}$, internal transcribed spacer-specific regions of $V$. dahliae or D, Ave1 on V. dahliae strains VdLu01, VdLs16, and VdLs17; expected amplicon size 334 bp (C) or 216 bp (D). Microscopic observation of hyphal structure: $\mathbf{E}$, apex of a conidiophore; $\mathbf{F}$, torulose cells surrounding a microsclerotium blue lactophenol staining; $\mathbf{G}$, heap of microsclerotia; and $\mathbf{H}$, isolated microsclerotium. Abbreviations: $c 0=$ conidium, $\mathrm{cp}=$ conidiophore, $\mathrm{ph}=$ phialide, $\mathrm{ms}=$ microsclerotia, and tc $=$ torulose cell. Bars $=20 \mu \mathrm{m}(\mathrm{E}), 40 \mu \mathrm{m}$ $(\mathrm{F}$ and $\mathrm{H})$, and $200 \mu \mathrm{m}(\mathrm{G})$. 
samples were sectioned because of their large size and longitudinal and cross-sections of stems were hand-cut under a binocular microscope. All samples were mounted on a glass slide with distilled water. Images were acquired by CLSM (TCS SP2 AOBS and TCS SP8 MP; Leica) at Primacen, Mont-Saint-Aignan, France. Observations were performed using $\times 10, \times 25, \times 40$, and $\times 100$ oil-immersion objectives. GFP fluorescence was detected by a 488-nm ray line of an argon laser and emissions were collected in the range of 498 to $570 \mathrm{~nm}$. Fluorescent and transmitted light captures were performed; overlay images and scales were obtained by ImageJ software (Rasband WS, 1997-2015; https://imagej.nih.gov/ij/).

Plant and fungal DNA extraction and quantification. Up to $50 \mathrm{mg}$ of plant (stem or straw, noninfected or infected) or fungus (pure culture) samples were transferred to $-20^{\circ} \mathrm{C}$ before use. Plant samples were previously finely cut before DNA extraction. Total DNA extraction was performed using a PowerPlant DNA Isolation kit (MoBio Laboratories, Carlsbad, CA, USA) following the manufacturer's instructions. Concerning fungal samples, a preliminary step was added. Fungal tissues were crushed with a sterile pestle and subsequently digested at $30^{\circ} \mathrm{C}$ overnight in $450 \mu \mathrm{l}$ of PowerPlant bead solution, with the addition of $400 \mathrm{U}$ of a lyticase solution (SigmaAldrich). Total DNA concentrations were assessed using a Fluorescent DNA quantification kit (Bio-Rad, Hercules, CA, USA) and a Varioskan Flash Multimode Reader (ThermoScientific, Waltham, MA, USA) following the manufacturer's instructions. All extracted DNA samples were stored at $-20^{\circ} \mathrm{C}$.

Verticillium race determination by specific polymerase chain reaction assay. Race-specific determination was performed using the primers Vd_Ave1_F1 (5'-ACTCGCCAGAAGAAGTCCAA-

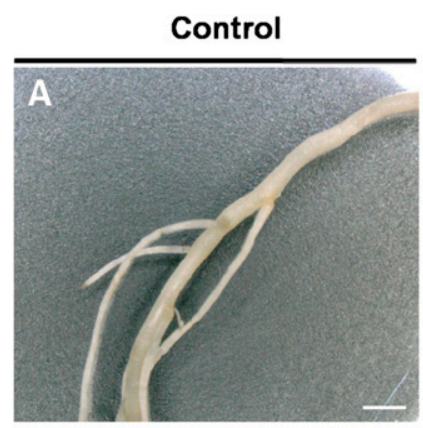

\section{V. dahliae inoculated}

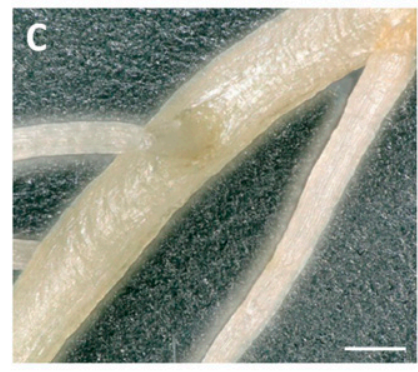

Control
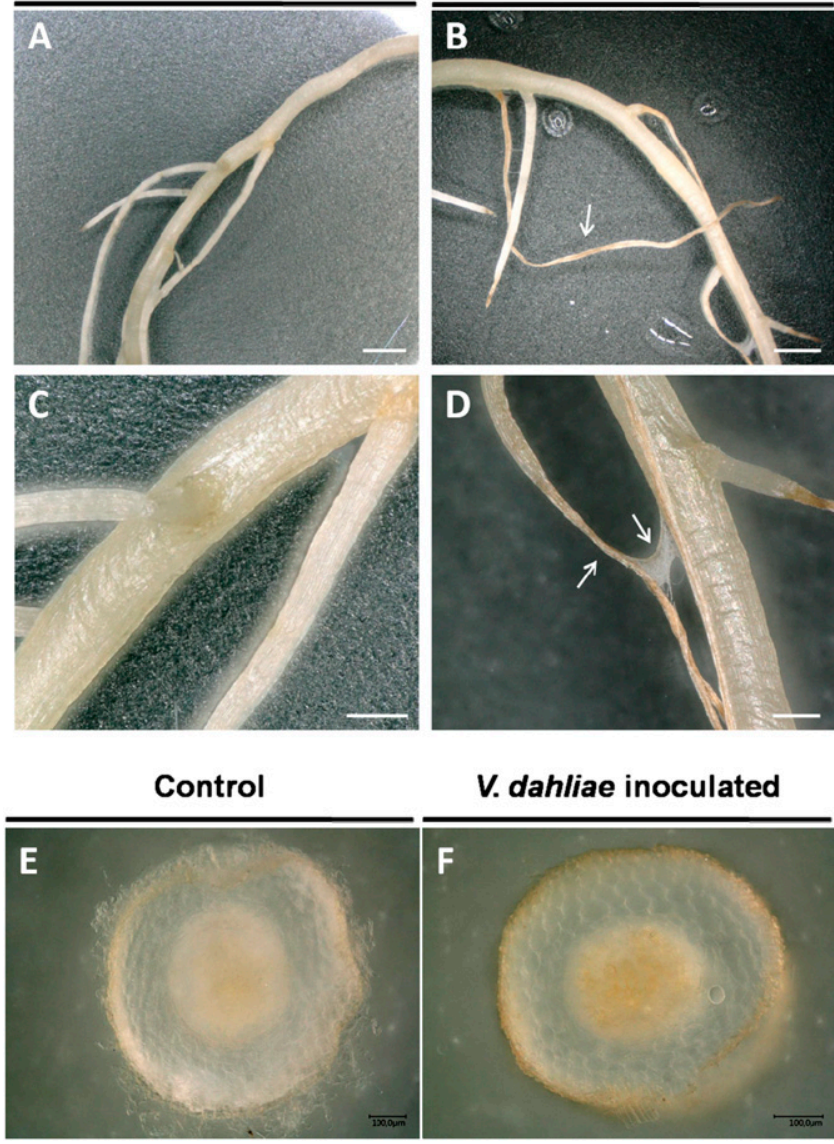

V. dahliae inoculated

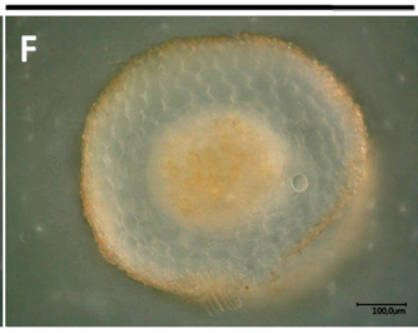

Fig. 2. B and D, Root symptoms on the zone of cell differentiation and lateral roots infected by the strains VdLu01 or VdLs17, 10 days postinoculation. A and C, Roots of control plants for comparison. Bars $=600 \mu \mathrm{m}$ (A and B) or $200 \mu \mathrm{m}$ (C and D). Cross-sections of $\mathbf{E}$, control and $\mathbf{F}$, inoculated roots 4 weeks postinoculation. Bars = $100 \mu \mathrm{m}$. $3^{\prime}$ ) and Vd_Ave1_R1 (5'-CCACAACAGGGAGACAGGTT-3') The primers were designed by Primer 3 software (Koressaar and Remm 2007; Untergasser et al. 2012). The Avel sequence obtained from $V$. dahliae strain St14.01 (accession number JQ625341) was used as template. In this experiment, strains that lack Avel could belong to race 2 . The strains VdLs16 race 1 and VdLs17 race 2 DNA were used as controls. Primers targeting the internal transcribed spacer (ITS) region (Vd-ITS1-45-F and Vd-ITS2-379-R) (Bressan et al. 2016) were used as a positive control to guarantee the presence of the DNA samples. End-point polymerase chain reaction (PCR) was performed in a $25-\mu \mathrm{l}$ reaction volume: $50 \mathrm{ng}$ of fungal DNA (pure culture), $0.1 \mu \mathrm{M}$ each primer (Vd_Ave1_F1 and Vd_Ave1_R1), and $12.5 \mu \mathrm{l}$ of GoTaq Green Master Mix (Promega Corp., Madison, WI, USA). PCR cycling was achieved using a GeneAmp PCR System 9700 (Applied Biosystems, Foster City, CA, USA) following a program of $95^{\circ} \mathrm{C}$ for $2 \mathrm{~min}$; then, 35 cycles of $95^{\circ} \mathrm{C}$ for $45 \mathrm{~s}, 60^{\circ} \mathrm{C}$ for $1 \mathrm{~min}$, and $72^{\circ} \mathrm{C}$ for $30 \mathrm{~s}$; and, finally, $72^{\circ} \mathrm{C}$ for $7 \mathrm{~min}$ for final extension. The PCR products, with an expected amplicon size of $216 \mathrm{bp}$, were visualized by electrophoresis on a $1 \%$ agarose gel stained by ethidium bromide.

V. dahliae detection on plant samples by PCR assay. V. dahliae detection was performed using the primers Vd-ITS1-45-F and VdITS2-379-R (Bressan et al. 2016). End-point PCR was performed in a $25-\mu 1$ reaction volume: $50 \mathrm{ng}$ of plant DNA (stem or straw, noninfected or infected), $0.1 \mu \mathrm{M}$ each primer (Vd-ITS1-45-F and VdITS2-379-R), and $12.5 \mu$ l of GoTaq Green Master Mix (Promega Corp.). PCR cycling was achieved using a GeneAmp PCR System 9700 (Applied Biosystems) following a program of $95^{\circ} \mathrm{C}$ for $2 \mathrm{~min}$; then, 35 cycles of $95^{\circ} \mathrm{C}$ for $45 \mathrm{~s}, 60^{\circ} \mathrm{C}$ for $1 \mathrm{~min}$, and $72^{\circ} \mathrm{C}$ for $30 \mathrm{~s}$; and, finally $72^{\circ} \mathrm{C}$ for $7 \mathrm{~min}$ for final extension. The PCR products, with an expected amplicon size of $334 \mathrm{bp}$, were visualized by electrophoresis on $1 \%$ agarose gel stained by ethidium bromide.

\section{Results}

Identification of VdLu01, a $V$. dahliae isolate from fiber flax. After growing for 1 week on PDB-agar medium, the strain VdLu01 produced a white colony (Fig. 1A); an abundant and floccose aerial mycelium was observed. According to morphological traits described by Inderbitzin et al. (2011), conidiophores were erect and branched, narrowing toward the apex, hyaline and septate. Phialides were flask shaped, arranged in whorls along conidiophores, pointed, and carrying ovoid and hyaline terminal conidia (Fig. 1E). Furthermore, when cultivated in MA-liquid medium for 1 month, $\mathrm{VdLu} 01$ formed microsclerotia composed of rounded, brown-pigmented cells (Fig. 1B and $\mathrm{H}$ ) embedded in a mycelial matrix (Fig. 1G). Occasionally, hyphae formed by torulose cells were attached to a microsclerotium (Fig. 1F). The ITS region specific to $V$. dahliae (Bressan et al. 2016) was detected on VdLu01 and the lettuce isolates VdLs16 and VdLs17 (Fig. 1C), whereas the Ave1 sequence was detected on neither VdLu01 nor VdLs17; thus, both could be assigned to race 2 (Fig. 1D).

Pathogen development and symptoms on root. Symptom observations were performed using the strains VdLu01 and VdLs17. In both infections, first root symptoms were triggered rapidly. Lateral roots exhibited dryness, and a brown discoloration on the surface was observed (Fig. 2B). Occasionally, these roots were tightly hanging on to the main root by fungal mycelium (Fig. 2D). Additionally, a brown discoloration of epidermis and vascular tissues in the main root was noticed (Fig. 2F).

Time-course tracking of pathogen development by CLSM was undertaken using the GFP-tagged VdLs17 strain. Two hours after inoculation performed by the root-dipping method, the entire root was covered by conidia, including the zone of cell differentiation, lateral roots, root hairs, zone of cell elongation, and root tips. Conidia were randomly distributed, isolated or in heaps and spotted on the root epidermis (Fig. 3C, D, and E). By $2 \mathrm{~h}$ postinoculation (hpi), germination of conidia was observed; only one germ tube emerged from one end per cell (Fig. 3A and B). At 1 day postinoculation (dpi), hyphae had grown parallel to the longitudinal axis of the root or not, occasionally developing secondary structures along the main hyphae (Fig. 3F, G, and $\mathrm{H}$ ). The growth pattern of most hyphae followed a random path 
but it is likely that the hyphae extended over a maximum area along the root surface (Fig. 3H). At the same time, some conidia germinated and developed a germ tube; others remained in a quiescent state on the root epidermis (Fig. 3F). Interestingly, whereas successful germination of conidia and hyphal development was found on the zone of cell differentiation and lateral roots, the zone of cell division and root tip were free of the pathogen. By $3 \mathrm{dpi}$, the pathogen developed from the tip of lateral roots (Fig. 3I) but, in addition, a large fungal mass extended into the zone of cell differentiation and lateral roots, encompassing the entire area, sometimes developing on the periphery (Fig. $3 \mathrm{~J})$. Consequently, these sections of roots were covered by the pathogen, causing dryness of lateral roots, collapse of tissues, and cessation of meristematic activity in some cases. These symptoms were correlated with the observations performed by the light reflection microscope. By 1 week postinoculation (wpi), the zone of cell differentiation was entirely colonized by the fungus. Most hyphae were oriented parallel to the longitudinal axis of the root (Fig. 3K and L). Simultaneously, on some areas of the zone of cell differentiation, each oriented mycelial hyphae developed several swelling structures similar to appressoria, in contact with the junction of two epidermal cells (Fig. 4A and B). It is likely that these weakly protected areas are the point of entry of intercellular colonization into the cortical tissues

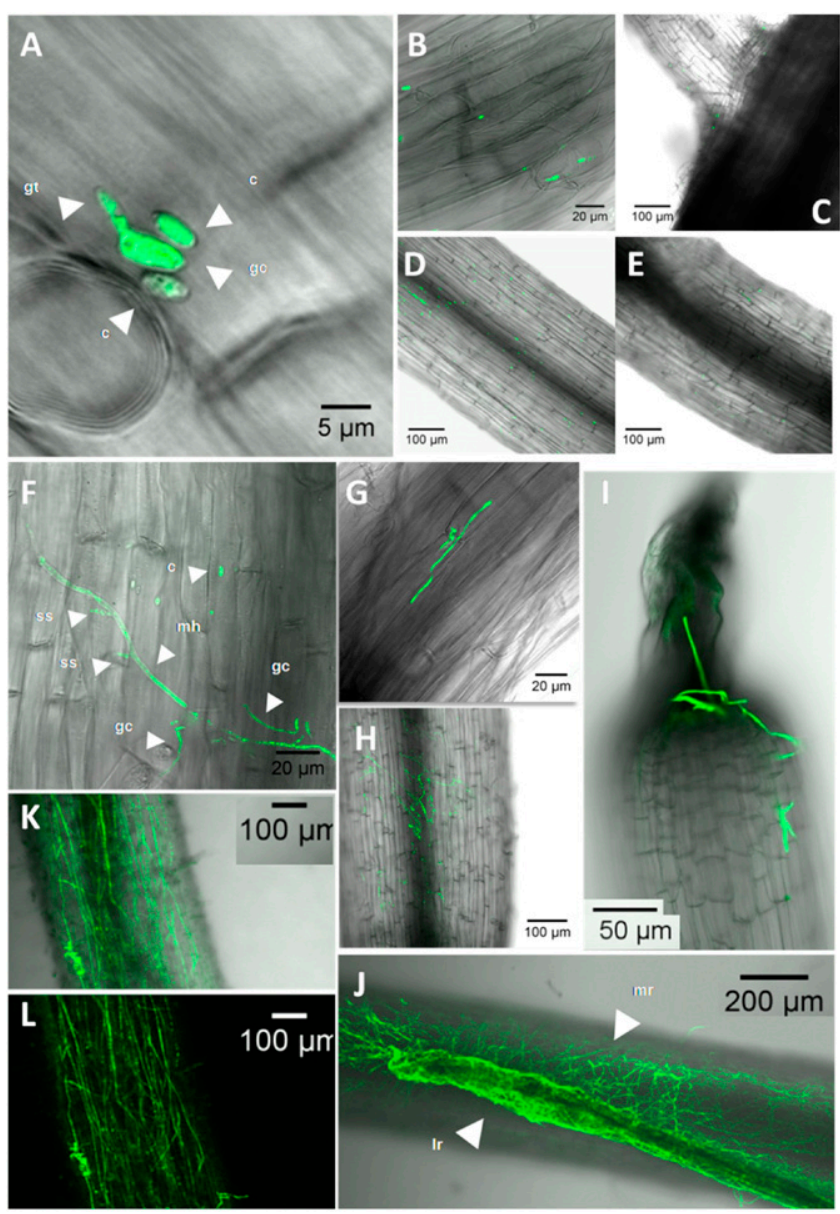

Fig. 3. Germination of conidia and early steps of hyphae growth of VdLs17 strain on flax roots. Overlay of a brightfield image and a fluorescent image. A and B, Germinated and nongerminated conidia on the zone of cell differentiation, $2 \mathrm{~h}$ postinoculation (hpi). $\mathbf{C}$ and $\mathbf{E}$, Conidia on the zone of cell differentiation, including lateral root junction (only C), 2 hpi. D, Conidia on the zone of cell elongation, $2 \mathrm{hpi}$. Growth of mycelia hyphae on the zone of cell differentiation $\mathbf{F}$ and $\mathbf{G}, 1$ day postinoculation (dpi) and $\mathrm{H}, 3 \mathrm{dpi}$. I, Hyphae caused dryness at the tip of a lateral root, $3 \mathrm{dpi}$. J, Fungal mass wrapped the zone of cell differentiation, including a lateral root, $3 \mathrm{dpi}$. K and L, Growth of mycelia hyphae on the zone of cell differentiation, 1 week postinoculation. L, Only fluorescent image. Abbreviations: $c 0=$ conidium, gc = germinated conidium, gt = germ tube, $\mathrm{mh}=$ main hypha, $\mathrm{ss}=$ secondary structure, $\mathrm{Ir}=$ lateral root, and $\mathrm{mr}=$ main root. leading to vascular colonization. However, no cortical intercellular colonization was observed. By 2 wpi, colonization of the root vascular system by the pathogen was clearly observed (Fig. 4C and C); a set of several hyphae followed the path of the vascular tissues (Fig. $4 \mathrm{E}$ and $\mathrm{F}$ ). As in the main root, vascular colonization occurred in lateral roots. The pathogen was always detected on the basal area, whereas it was still absent from apical areas of the root. Interestingly, once vascular colonization was established, no additional pathogen was observed on the root surface (Fig. 4C, F, and G). Crosssections of the main root at 4 wpi confirmed the pathogen colonization within the xylem vessels (Fig. 4G, H, and I). Not all vessels were filled by the pathogen (Fig. 4G, H, and I), and those contaminated were filled with different amounts of hyphae (Fig. 4H).

Pathogen development and symptoms on stem and leaves. In VdLu01 infections, some early symptoms occasionally appeared on seedlings or plants with growth retardation after $1 \mathrm{wpi}$ : apical leaves exhibited chlorosis and an altered morphology (data not shown). In both infections (VdLu01 or VdLs17), wilting symptoms on leaves started between 3 and 4 wpi (Fig. 5B). Necrosis was displayed first at the leaf tips, which turned yellow and rolled up (Fig. 5A). Over the following weeks, necrosis extended to the whole leaf but did not reach or affect the stem, and falling leaves could be observed (Fig.
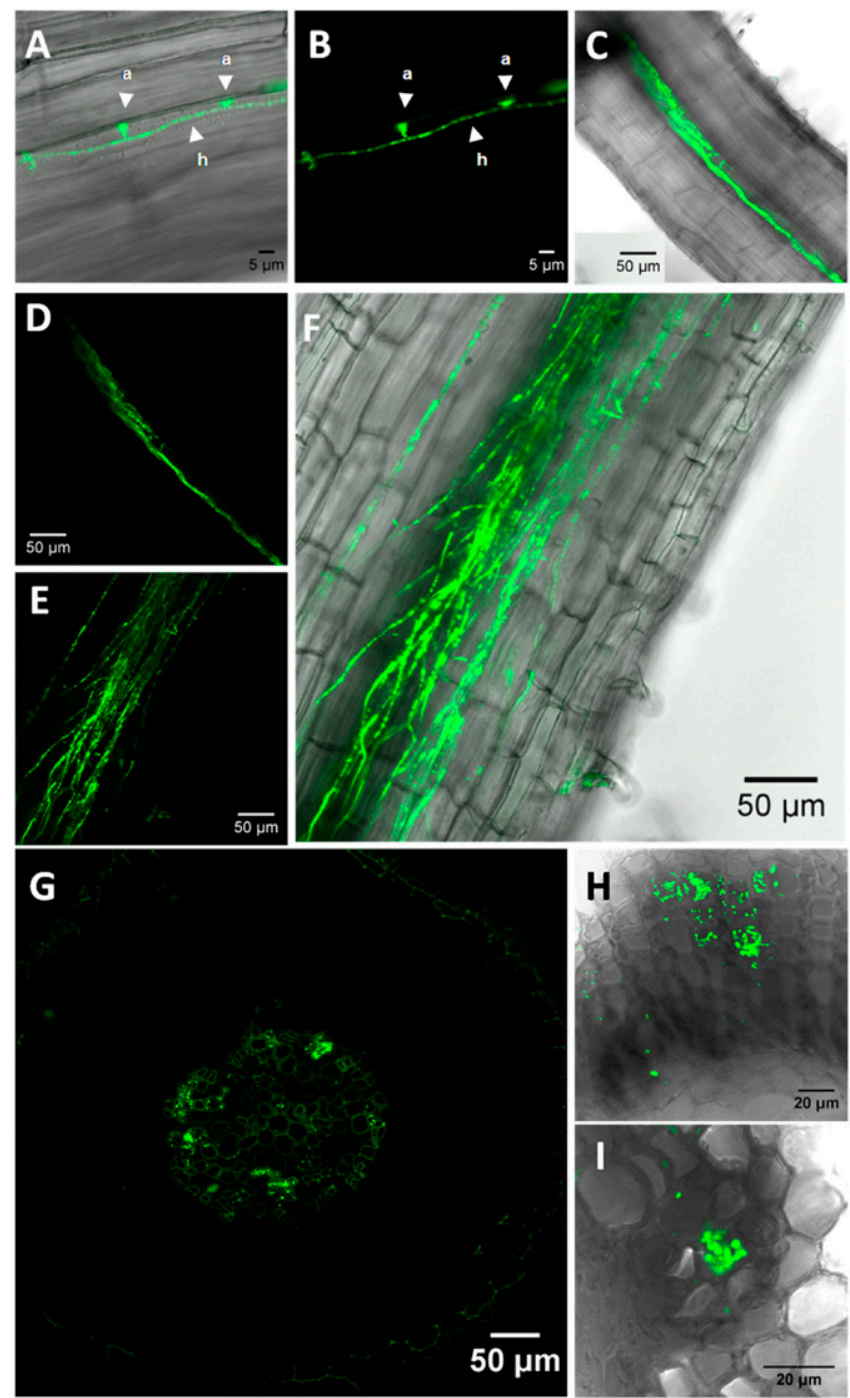

Fig. 4. Vascular colonization of VdLs17 strain on flax roots. Overlay of a brightfield image and a fluorescent image. A and B, Mycelia hyphae developing appressorialike structures on intercellular junction of the zone of cell differentiation, 1 week postinoculation (wpi). B, Only fluorescent image. $\mathbf{C}$ to I, Vascular colonization of the pathogen in a main root, 2 wpi. Cross-sections, 4 wpi (G to I). D, E, and G, Only fluorescent images. G, Image stacking (10 images), depth $=60 \mu \mathrm{m}$. Abbreviations: $\mathrm{a}=$ appressorium-like and $\mathrm{h}=$ hyphae. 
5A). These symptoms were always observed first at the base and then spread to the apex, clearly showing the growing symptoms to be acropetal (Fig. 5B). However, this growth of symptoms appeared to be very slow. Furthermore, a brown vascular discoloration was observed within the basal part of the stem (hypocotyl) at 4 wpi (Fig. 5D).

Further CLSM investigations at 4 wpi confirmed extensive pathogen colonization within the root whereas a weak fluorescent signal was detected within the hypocotyl (Fig. 6A and B). Moreover, neither symptomatic leaves nor the apical part of the stem revealed the presence of the pathogen. Therefore, symptoms, including brown discoloration and wilting leaves, appeared well in advance of the presence of the pathogen. Nevertheless, growth into vascular tissues was slow. Between 6 and 8 wpi, observations on the stem were then performed between the cotyledon and 10th leaf. Longitudinal sectioning of the stem was necessary to detect the GFP signal; actually, it revealed a high signal around the pith showing the acropetal growth of pathogen hyphae (Fig. 6H). Nevertheless, the pathogen did not colonize the entire area around the pith. No hyphal progression was observed toward the leaves. Further information was obtained by observation of the stem cross-sections. Similar to what was observed in the root, xylem vessels were partially colonized by various quantities of pathogen hyphae (Fig. $6 \mathrm{~F}$ and $\mathrm{G}$ ), and several neighboring vessels, or only a single vessel, were occasionally colonized (Fig. 6C and E). Finally, at this time, the pathogen could disturb the hydraulic system but the fiber bundles were not invaded (Fig. 6D and E). Symptomatic lower and upper leaf samples were collected and did not exhibit macroscopic differences. The pathogen invaded vascular tissues of the midrib and veins in lower leaves only (Fig. 6I). The pathogen did not colonize the entire leaf, only the basal area toward the apical area (Fig. 6J).

Observations of Verticillium wilt in field. At the capsule stage, wilted plants were randomly distributed within an area of the plot (Fig. 7A). On the infected plants sampled, the global aspect of infected plants exhibited typical wilting symptoms and fewer capsules were observed as compared with the noninfected plants (Fig. 7C and D). Stems were dried and chlorotic on apical parts, containing small black spots

A
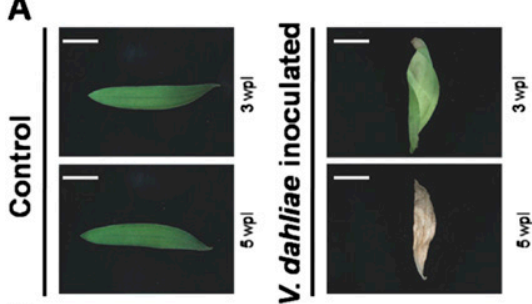

B
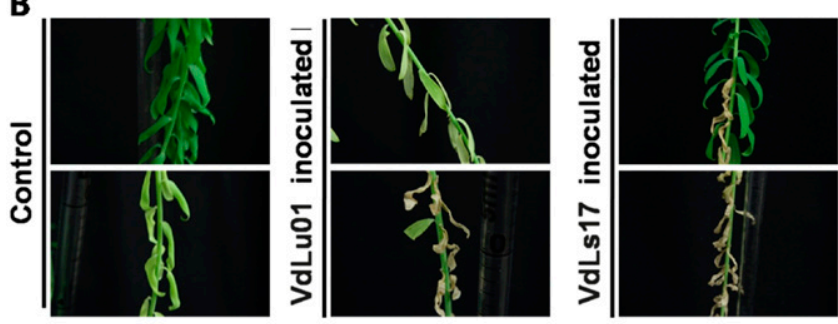

Control

V. dahliae inoculated

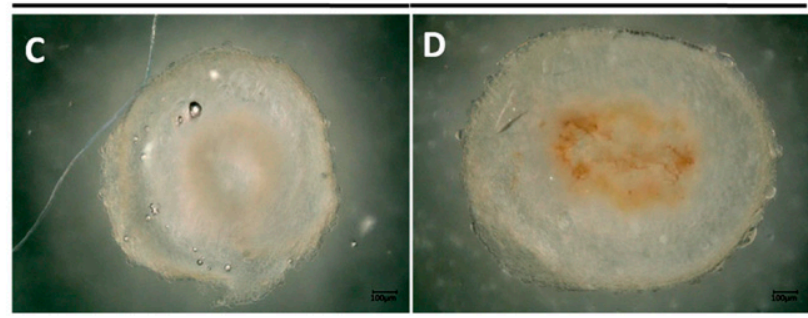

Fig. 5. Symptoms of Verticillium wilt on stem and leave of flax. A, Wilting symptom on a basal leaf at 3 and 5 weeks postinoculation (wpi) and control leaf. Bars $=5 \mathrm{~mm}$. B, Wilting symptoms at the plant level infected by VdLu01 or VdLs17, apical and basal level, 5 wpi, and control plant for comparison. Cross-sections of C, control and D, inoculated roots, 4 wpi. Bars $=100 \mu \mathrm{m}$.
(Fig. 7E). Leaves were rolled up and contained black fungal mycelium (Fig. 7D). On the brittle straws sampled after retting, reflection microscopy revealed numerous black microsclerotia on the surface of brittle straws (Fig. 7F). Several dry fungal structures similar to brownpigmented torulose cells were observed on the internal parts of the epidermal tissues, seemingly forming a microsclerotium (Fig. 7G). After retting, the bast fiber bundle was easily removable from the straw and also contained numerous black microsclerotia (Fig. $7 \mathrm{H}$ ). Closest investigations revealed that microsclerotia were embedded inside the bast fiber bundle (Fig. 7I) and, thus, potentially involved in brittleness of infected fibers. PCR amplification confirmed the presence of $V$. dahliae on both infected plants and brittle straws (Fig. 7B).

\section{Discussion}

Here, we provide the first report of how the pathogen $V$. dahliae develops in fiber flax roots and aboveground parts using VdLs17 isolated from lettuce and previously transformed with the GFP gene. The strain VdLs17 belongs to race 2 (Vallad et al. 2006) and lacks the Avel sequence, as does the strain VdLu01 isolated from fiber flax. Fiber flax exhibits similar wilting symptoms after 3 or 4 weeks when inoculated by VdLs17 or VdLu01 in both inoculation systems. Therefore, VdLs17 can be considered to be a flax pathogen. Bhat and Subbarao (1999) have reported cross-pathogenicity of isolates from specific crops on a set of host plants (e.g., bell pepper, cabbage, cauliflower, cotton, eggplant, and mint isolates). In addition, Nicotiana benthamiana exhibits wilting symptoms after 12 days when inoculated by the lettuce strain VdLs17 (Klosterman et al. 2011). These observations support the idea that $V$. dahliae rapidly adapts to new niche hosts.

Although microsclerotia are the primary source of inoculum in infested soils, conidia suspensions were preferentially selected to

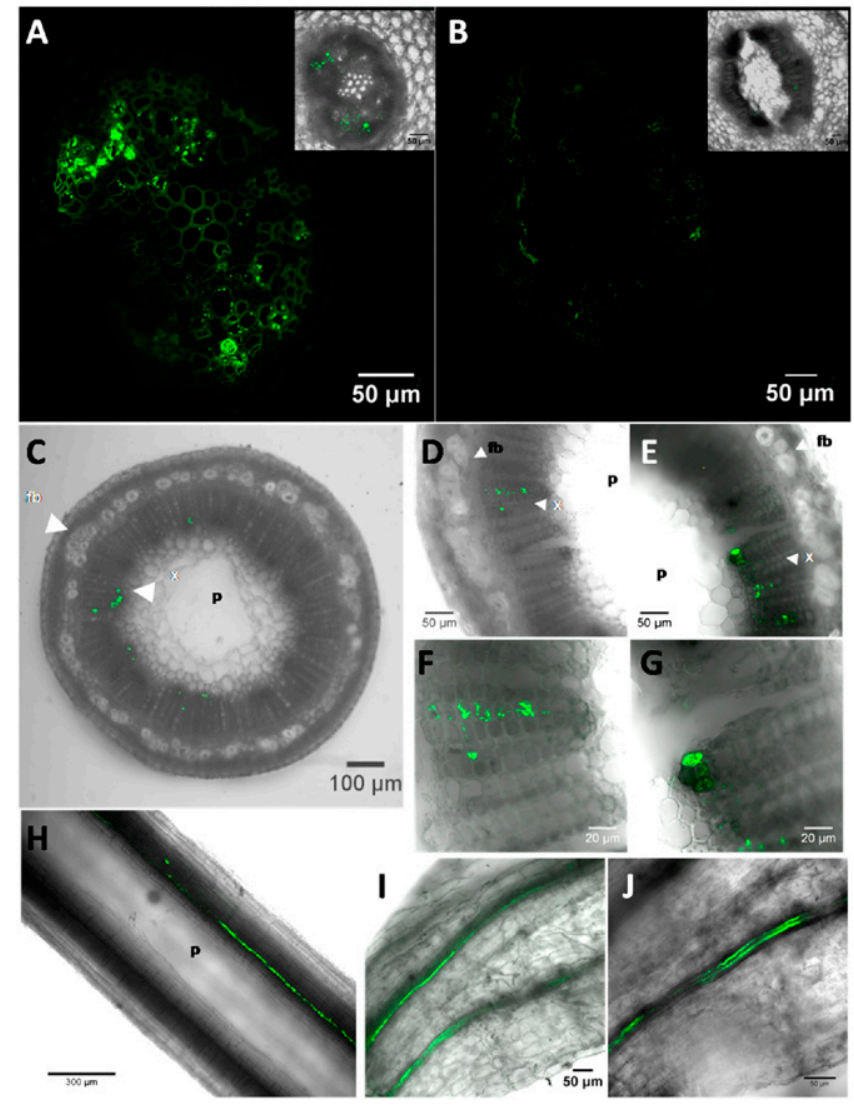

Fig. 6. Vascular colonization of VdLs17 strain within the aboveground parts. Overlay of a brightfield image and a fluorescent image. A, and B, Comparison of pathogen fluorescence within xylem cross-sections of root and stem (hypocotyl) on the same plant, only fluorescent images, 4 weeks postinoculation (wpi). C to J, Between 6 and 8 wpi. C to G, Growth of mycelia hyphae within stem cross-section. $\mathbf{H}$, Growth of mycelia hyphae within stem transversal section. I and J, Growth of mycelia hyphae within basal part of a symptomatic leaf. Abbreviations: $\mathrm{fb}=$ fiber bundle, $P=$ pith, and $X=x y l e m s$. 
initiate infection because conidia are quite uniform, making them easier to prepare and quantify relative to microsclerotia (Vallad and Subbarao 2008). In our report, three different main steps are distinguishable: development on the root epidermis was broadly asymptomatic, followed by colonization within the root xylems and then of the stem and leaves, leading to symptoms. During the first steps of infection, conidia probably germinated due to root exudates that overcome fungistasis (Schreiber and Green 1963), giving rise to
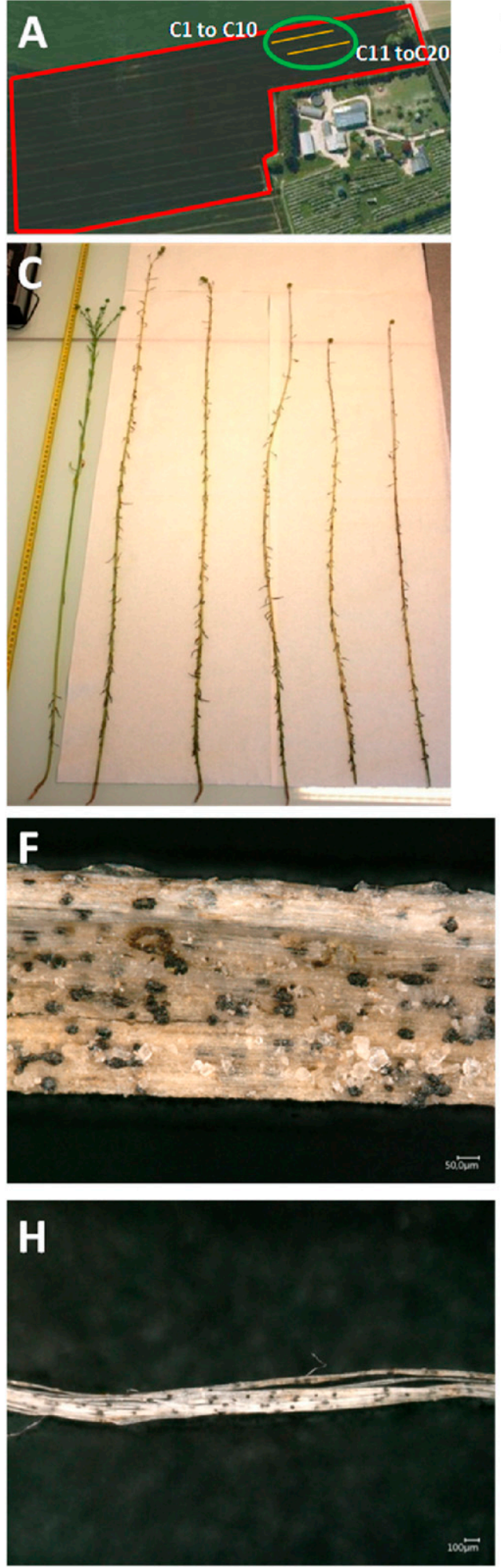
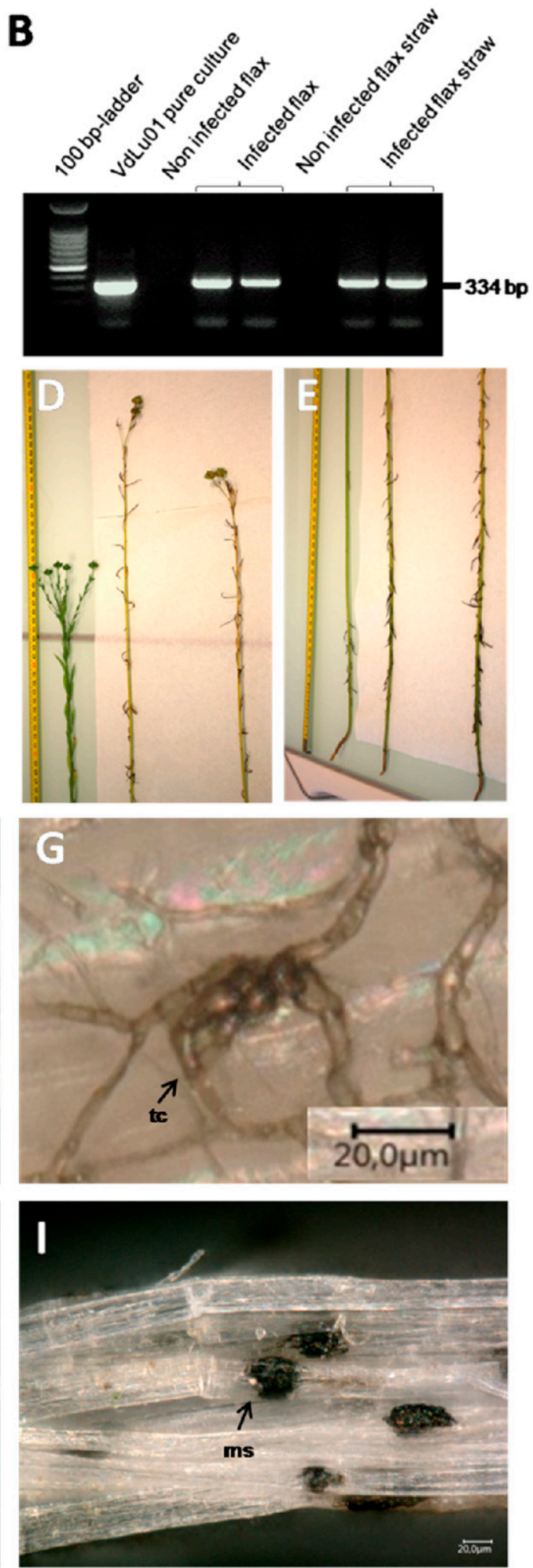

Fig. 7. Verticillium wilt caused by Verticillium dahliae on flax at the capsule stage and after retting. A, Delimitation of the fiber flax plot investigated (red lines), area where the infectious site was detected (green circle), and C1 to C20 (yellow lines) = points where the infected plants were sampled. B, Polymerase chain reaction amplification using primers targeting internal transcribed spacer-specific regions of V. dahliae on V. dahliae strain VdLu01, noninfected flax, infected flax, noninfected flax straw, and infected flax straw. Expected amplicon size $=334 \mathrm{bp}$. C to E, Wilting symptoms on aboveground parts (nonaffected plant on left). Close-up view: $\mathbf{D}$, apical parts and E, basal parts. $\mathbf{F}$ to $\mathbf{I}$, Fungal structures of $V$. dahliae on fiber flax stem after retting. F, Microsclerotia observed on a straw surface. G, Brown-pigmented torulose hyphal cells attached on the internal parts of the epidermal tissues. $\mathbf{H}$, Microsclerotia on bast fiber bundles. I, Close-up view showing microsclerotia embedded in bast fiber bundle. Abbreviations: ms = microsclerotium and tc $=$ torulose hyphal cells. Bars $=50 \mu \mathrm{m}(\mathrm{F}), 20 \mu \mathrm{m}(\mathrm{G}$ and I), and $100 \mu \mathrm{m}(\mathrm{H})$. 
mycelia hyphae that extend over a maximum area between $2 \mathrm{hpi}$ and $1 \mathrm{dpi}$. Subsequently, the pathogen develops at 3 dpi only on the zone of cell differentiation and lateral roots, causing dryness, brown discoloration, and collapse of tissues as a consequence of massive surface colonization. This fungal mass tends to organize itself along the longitudinal axis of the epidermal cells at 7 days. In contrast, Zhang et al. (2012) observed pathogen development on the meristematic and elongation zones of cotton roots. Nevertheless, colonization of lateral roots leading to a successful infection was reported on Arabidopsis and lettuce (Vallad and Subbarao 2008; Zhao et al. 2014). Zhao et al. (2014) reported in Arabidopsis that, despite massive hyphae encompassing the root surface, only a few hyphae successfully invaded the root internal tissues. The same observation was previously reported for cotton roots (Zhang et al. 2012). Observations at $7 \mathrm{dpi}$ revealed that several swelling structures similar to appressoria developed along mycelia hyphae on the root surface. The pathogen tends to colonize inner tissues through epidermal cell junctions. These observations confirm the presence of appressoria as structures of penetration. However, pathogen colonization did not spread onto the zone of cell elongation and root tips after $1 \mathrm{dpi}$, contrary to reports on spinach, cotton, and lettuce (Maruthachalam et al. 2013; Vallad and Subbarao 2008; Zhang et al. 2012), suggesting that these zones are particularly distant from the infection in this study. Indeed, the zone of cell elongation is generally considered to be a major site for the exudation of secondary metabolites (McDougall and Rovira 1970). A previous study noted that microbe-associated molecular patterns such as the flagellar peptide (Flg22) and peptidoglycan (PGN) trigger a defense response in the epidermal layer of the cell elongation zone in Arabidopsis (Millet et al. 2010). Border cells, which are separated from the root tip of higher plants and produce metabolites in the rhizosphere (Hawes et al. 2000), protect the pea root meristem when infected by Nectria hematococca (Gunawardena and Hawes 2002; Gunawardena et al. 2005). Border-like cells of Arabidopsis and flax respond to Flg22 and PGN by triggering an oxidative burst, the expression of defense-related genes, and cell wall redistribution of extensins (Plancot et al. 2013).

Vascular colonization into roots was observed for the first time at 2 wpi in the main root as well as in lateral roots but the colonization of xylems was incomplete. In susceptible lettuce taproots, restricted advancement of mycelia through xylem vessels has also been observed (Vallad and Subbarao 2008). This is in contrast to observations in spinach, where all xylem vessels are heavily colonized (Maruthachalam et al. 2013). The pathogen remains in roots during the following 2 weeks. It was suggested that wilt pathogens exploit this niche to avoid competition with other microbes (McCully 2001). The xylem is a nutritionally poor environment; nevertheless, analysis of whole-genome sequences reveals that the $V$. dahliae genome is enriched in genes encoding cell-wall-degrading enzymes (CWDE), which are implicated in cell wall degradation to release sugar as a source of nutrition (Klosterman et al. 2011). Once entering xylem vessels, $V$. dahliae is faced with a set of plant defense reactions combining tyloses, pectin gels and gums, phenolic compounds, and inorganic sulfur (Yadeta and Thomma 2013).

In our study, common wilting symptoms emerged between 3 and 4 weeks after $V$. dahliae inoculation and grew acropetally. Wilting symptoms are also a consequence of $F$. oxysporum $\mathrm{f}$. sp. lini infection (Kroes et al. 1999); reports in the field show that Fusarium wilt can occur at any time of the growing season, and symptoms generally start on upper leaves (Rashid 2003). Therefore, basipetal development of foliar symptoms is a feature of Fusarium wilt whereas acropetal symptom development is a feature of Verticillium wilt. Based on this difference, symptom diagnosis in the field could distinguish Fusarium wilt from Verticillium wilt. In addition, as recommended for an early diagnostic on lettuce (Vallad et al. 2006), the onset of the root vascular brown discoloration in advance of the pathogen could be an early diagnostic on fiber flax as well. Because of a lack of a reliable diagnosis for Verticillium wilt in early steps of cultivation, combining PCR with symptomatology of plant samples could be an efficient approach to detecting cases of Verticillium wilt in the field. In recent years, real-time PCR has gained in popularity for Verticillium wilt detection and quantification in seed (Karajeh 2006; Maruthachalam et al. 2013), environmental samples (Banno et al. 2011; Bilodeau et al.
2012), and symptomatic plants from the field (Atallah et al. 2007; Mercado-Blanco et al. 2003) because it is accurate and sensitive. Necrotic leaves at 4 weeks did not display the presence of the pathogen; it takes two additional weeks to detect hyphae within the midrib and veins of leaves. On infected lettuce, Vallad and Subbarao (2008) reported the presence of hyphae moving through the midrib and veins within chlorotic regions of leaves occurring after symptoms appear. Actually, there is no consensus about the physiological and biochemical basis of Verticillium wilt symptoms. Several studies demonstrated $V$. dahliae secretome activity that is detrimental to plant tissues such as Nep or NEP protein elicitors. Recombinant VdNEP causes symptoms on tobacco and cotton and, although recombinant NLP1 and NLP2 cause symptoms on tobacco, only the NLP1 knockout mutant stops symptoms on tobacco (Santhanam et al. 2013; Wang et al. 2004; Wang et al. 2012). Other studies note the symptoms to be an unfortunate secondary consequence of the host response; among them, the TMP1 protein, a defense response to $V$. dahliae, contributes to one aspect of symptom development: namely, water restriction and wilting of the host (Robb et al. 1983, 1989).

Finally, between 6 and 8 wpi, the pathogen was sequestered within stem xylem vessels. However, pathogen progression had not yet reached the bast fiber bundle. Generally, fiber flax cultivation requires at least 120 days to obtain long fibers, followed by a retting process to dissociate the fibers from the other parts of the stem. Damage caused by Verticillium wilt to fiber flax differs from other crops because the inner tissues (bast fiber bundles) are affected and, therefore, unmarketable. It could be suggested that fiber deterioration can occur later, once the plant is no longer capable of protecting itself (i.e., during retting). Our report in the field revealed that $V$. dahliae had reached the fiber after retting and numerous microsclerotia were embedded inside the bast fiber bundle, consequently potentially contributing to weakening of the fiber. Cellulose is the major compound of the fiber's secondary cell wall, ranging from 65 to $80 \%$ of dry weight at maturity. Cellulose is encompassed into a hemicellulose and pectin matrix that ensures cohesion (Baley 2002; Focher et al. 1992; Morvan et al. 1989). Analysis of the $V$. dahliae genome shows genes encoding CWDE, including polysaccharide lyases, glycoside hydrolases, carbohydrate binding modules, glycosyl transferases, and carbohydrate esterases. Polysaccharide lyases are well represented in the $V$. dahliae genome in comparison with other Ascomycota; therefore, $V$. dahliae is able to cleave different forms of pectin (Klosterman et al. 2011). Accordingly, the process of how and when the fiber is degraded by the pathogen remains an interesting question.

\section{Acknowledgments}

We thank D. Chapman and M. Bénard at the Primacen platform for their help with CLSM, Terre de lin for supplying fiber flax seed, and the Department of Plant Pathology (University of California, Davis) for supplying V. dahliae GFPexpressing strains VdLs16 and VdLs17.

\section{Literature Cited}

Agrios, G. N. 1997. Plant Pathology. Academic Press, San Diego, CA

Agrios, G. N. 2005. Plant Pathology. Elsevier Academic Press, Burlington, MA

Atallah, Z. K., Bae, J., Jansky, S. H., Rouse, D. I., and Stevenson, W. R. 2007. Multiplex real-time quantitative PCR to detect and quantify Verticillium dahliae colonization in potato lines that differ in response to Verticillium wilt. Phytopathology 97:865-872.

Baley, C. 2002. Analysis of flax fibres tensile behaviour and analysis of the tensile stiffness increase. Composites Part A. 33:939-948.

Banno, S., Saito, H., Sakai, H., Urushibara, T., Ikeda, K., Kabe, T., Kemmochi, I., and Fujimura, M. 2011. Quantitative nested real-time PCR detection of Verticillium longisporum and V. dahliae in the soil of cabbage fields. J. Gen. Plant Pathol. 77:282-291.

Bejarano-Alcázar, J., Termorshuizen, A. J., and Jiménez-Díaz, R. M. 1999. Singlesite root inoculations on eggplant with microsclerotia of Verticillium dahliae. Phytoparasitica 27:279-289.

Bhat, R. G., and Subbarao, K. V. 1999. Host range specificity in Verticillium dahliae. Phytopathology 89:1218-1225.

Bilodeau, G. J., Koike, S. T., Uribe, P., and Martin, F. N. 2012. Development of an assay for rapid detection and quantification of Verticillium dahliae in soil. Phytopathology 102:331-343.

Bressan, M., Blum, A., Castel, L., Trinsoutrot-Gattin, I., Laval, K., and Gangneux C. 2016. Assessment of Verticillium flax inoculum in agroecosystem soils using real-time PCR assay. Appl. Soil Ecol. 108:176-186. 
de Jonge, R., van Esse, H. P., Maruthachalam, K., Bolton, M. D., Santhanam, P., Saber, M. K., Zhang, Z., Usami, T., Lievens, B., and Subbarao, K. V. 2012. Tomato immune receptor $V e 1$ recognizes effector of multiple fungal pathogens uncovered by genome and RNA sequencing. Proc. Natl. Acad. Sci. USA 109:5110-5115.

DeVay, J. E., Forreste, L. L., Garber, R. H., and Butterfield, E. J. 1974. Characteristics and concentration of propagules of Verticillium dahliae in airdried field soils in relation to prevalence of Verticillium wilt in cotton. Phytopathology 64:22-29.

Diwan, N., Fluhr, R., Eshed, Y., Zamir, D., and Tanksley, S. D. 1999. Mapping of $V e$ in tomato: A gene conferring resistance to the broad-spectrum pathogen, Verticillium dahliae race 1. Theor. Appl. Genet. 98:315-319.

Eastburn, D. M., and Chang, R. J. 1994. Verticillium dahliae: A causal agent of root discoloration of horseradish in Illinois. Plant Dis. 78:496-498.

Fitt, D. D. L., Bauers, F., Burhenne, S., and Paul, V. H. 1992. Occurrence of Verticillium dahliae on linseed (Linum usitatissimum) in the UK and Germany. Plant Pathol. 41:86-90.

Fitzell, R., Evans, G., and Fahy, P. C. 1980. Studies on the colonization of plant roots by Verticillium dahliae Klebahn with use of immunofluorescent staining. Aust. J. Bot. 28:357-368.

Focher, B., Marzetti, A., and Sharma, H. S. S. 1992. Changes in the structure and properties of flax during processing. Pages 329-342 in: Biology and Processing of Flax. H. S. S. Sharma and C. F. van Sumere, eds. M. Publications, Belfast, Northern Ireland.

FAO. 2016. FAOSTAT Database. Food and Agriculture Organization of the United Nations, Rome, Italy. Retrieved November 07, 2017 from http:// www.fao.org/faostat/en/.

Fradin, E. F., and Thomma, B. P. H. J. 2006. Physiology and molecular aspects of Verticillium wilt diseases caused by $V$. dahliae and V. albo-atrum. Mol. Plant Pathol. 7:71-86.

Fradin, E. F., Zhang, Z., Ayala, J. C. J., Castroverde, C. D. M., Nazar, R. N., Robb, J., Liu, C. M., and Thomma, B. P. H. J. 2009. Genetic dissection of Verticillium wilt resistance mediated by tomato Ve1. Plant Physiol. 150:320-332.

Gerik, J. S., and Huisman, O. C. 1988. Study of field-grown cotton roots infected with Verticillium dahliae using an immunoenzymatic staining technique. Phytopathology 78:1174-1178.

Grogan, R., Ioannou, N., Schneider, R., Sall, M., and Kimble, K. 1979. Verticillium wilt on resistant tomato cultivars in California: Virulence of isolates from plants and soil and relationship of inoculum density to disease incidence. Phytopathology 69:1176-1180.

Gunawardena, U., and Hawes, M. C. 2002. Tissue specific localization of root infection by fungal pathogens: Role of root border cells. Mol. Plant-Microbe Interact. 15:1128-1136.

Gunawardena, U., Rodriguez, M., Straney, D., Romeo, J. T., VanEtten, H. D., and Hawes, M. C. 2005. Tissue-specific localization of pea root infection by Nectria haematococca. Mechanisms and consequences. Plant Physiol. 137:1363-1374.

Hawes, M. C., Gunawardena, U., Miyasaka, S., and Zhao, X. 2000. The role of root border cells in plant defense. Trends Plant Sci. 5:128-133.

Hoagland, D. R., and Arnon, D. I. 1950. The water-culture method for growing plants without soil. Calif. Agric. Exp. Stn. Circ. 347:1-32.

Hoffmann, G. M., and Rondomanski, W. 1959. Eine Verticilliose des Leins (Linum usitatissimum L.) in Deutschland. Nachrichtenbl. Dtsch. Pflanzenschutzdienst (Berlin) 13:91-92.

Inderbitzin, P., Bostock, R. M., Davis, R. M., Usami, T., Platt, H. W., and Subbarao, K. V. 2011. Phylogenetics and taxonomy of the fungal vascular wilt pathogen Verticillium, with the descriptions of five new species. PLoS One 6:e28341.

Inderbitzin, P., and Subbarao, K. V. 2014. Verticillium systematics and evolution: How confusion impedes verticillium wilt management and how to resolve it. Phytopathology 104:564-574.

Karajeh, M. R. 2006. Seed transmission of Verticillium dahliae in olive as detected by a highly sensitive nested PCR-based assay. Phytopathol. Mediterr. 45:15-23.

Kawchuk, L. M., Hachey, J., Lynch, D. R., Kulcsar, F., van Rooijen, G., Waterer, D. R., Robertson, A., Kokko, E., Byers, R., Howard, B. J., Fischer, R., and Prüfer, D. 2001. Tomato Ve disease resistance genes encode cell surface-like receptors. Proc. Natl. Acad. Sci. USA 98:6511-6515.

Klosterman, S. J., Atallah, Z. K., Vallad, G. E., and Subbarao, K. V. 2009. Diversity pathogenicity and management of Verticillium species. Annu. Rev. Phytopathol. 47:39-62.

Klosterman, S. J., Subbarao, K. V., Kang, S., Veronese, P., Gold, S. E., Thomma, B. P. H. J., Chen, Z., Henrissat, B., Lee, Y.-H., Park, J., Garcia-Pedrajas, M. D., Barbara, D. J., Anchieta, A., de Jonge, R., Santhanam, P., Maruthachalam, K., Atallah, Z., Amyotte, S. G., Paz, Z., Inderbitzin, P., Hayes, R. J., Heiman, D. I., Young, S., Zeng, Q., Engels, R., Galagan, J., Cuomo, C. A., Dobinson, K. F., and Ma, L.-J. 2011. Comparative genomics yields insights into niche adaptation of plant vascular wilt pathogens. PLoS Pathol. 7:e1002137.

Koressaar, T., and Remm, M. 2007. Enhancements and modifications of primer design program Primer3. Bioinformatics 23:1289-1291.

Krikun, J., and Bernier, C. C. 1990. Morphology of microsclerotia of Verticillium dahliae in roots of gramineous plants. Can. J. Plant Pathol. 12:439-441.

Kroes, G. M. L. W., Loffler, H. J. M., Parlevliet, J. E., Keizer, L. C. P., and Lange, W. 1999. Interactions of Fusarium oxysporum f. sp. lini, the flax wilt pathogen, with flax and linseed. Plant Pathol. 48:491-498.
Marchal, M. E. 1940. Observations et recherches effectuées à la station de phytopathologie de l'état pendant l'année 1939. Bull. Inst. Agron. Gembloux 9:1-15.

Maruthachalam, K., Klosterman, S. J., Anchieta, A., Mou, B., and Subbarao, K. V. 2013. Colonization of spinach by Verticillium dahliae and effects of pathogen localization on the efficacy of seed treatments. Phytopathology 103: 268-280.

McCully, M. E. 2001. Niches for bacterial endophytes in crop plants: A plant biologist's view. Funct. Plant Biol. 28:983-990.

McDougall, B. M., and Rovira, A. D. 1970. Sites of exudation of 14 C-labelled compounds from wheat roots. New Phytol. 69:999-1003.

Mercado-Blanco, J., Collado-Romero, M., Parrilla-Araujo, S., RodríguezJurado, D., and Jiménez-Díaz, R. M. 2003. Quantitative monitoring of colonization of olive genotypes by Verticillium dahliae pathotypes with real-time polymerase chain reaction. Physiol. Mol. Plant Pathol. 63: 91-105.

Millet, Y. A., Danna, C. H., Clay, N. K., Songnuan, W., Simon, M. D., WerckReichhart, D., and Ausubel, F. M. 2010. Innate immune responses activated in Arabidopsis roots by microbe-associated molecular patterns. Plant Cell 22: 973-990.

Morvan, C., Abdul-Hafez, A., Morvan, O., Jauneau, A., and Demarty, M. 1989. Physicochemical and biochemical studies of polysaccharides solubilized from under-retted flax. Plant Physiol. Biochem. 27:451-459.

Pegg, G. F., and Brady, B. L. 2002. Verticillium Wilts. CAB International, Oxford.

Plancot, B., Santaella, C., Jaber, R., Kiefer-Meyer, M. C., and Follet-Gueye, M.-L. 2013. Deciphering the responses of root border-like cells of Arabidopsis and flax to pathogen-derived elicitors. Plant Physiol. 163: 1584-1597.

Rashid, K. Y. 2003. Principal diseases of flax. Pages 102-133 in: Flax, the Genus Linum. A. Muir and N. Westcott, eds. Taylor \& Francis, London.

Rick, C. M., Martin, F. M., and Gentile, A. 1959. Linkage of Verticillium resistance $(V e)$. Tomato Genet. Coop. 9:44.

Robb, E. J., Powell, D. A., and Street, P. F. S. 1989. Vascular coating: A barrier to colonization by the pathogen in Verticillium wilt of tomato. Can. J. Bot. 67: 600-607.

Robb, E. J., Street, P. F. S., and Busch, L. V. 1983. Basic fuchsin: A vascular dye in studies of Verticillium-infected chrysanthemum and tomato. Can. J. Bot. 61: $3355-3365$

Santhanam, P., van Esse, H. P., Albert, I., Faino, L., Nürnberger, T., and Thomma, B. P. 2013. Evidence for functional diversification within a fungal NEP1-like protein family. Mol. Plant-Microbe Interact. 26:278-286.

Schaible, L., Cannon, O. S., and Waddoups, V. 1951. Inheritance of resistance to Verticillium wilt in a tomato cross. Phytopathology 41:986-990.

Schreiber, L. R., and Green, R. J. 1963. Effect of root exudates on germination of conidia and microsclerotia of Verticillium albo-atrum inhibited by the soil fungistatic principle. Phytopathology 53:260-264.

Untergasser, A., Cutcutache, I., Koressaar, T., Ye, J., Faircloth, B. C., Remm, M., and Rozen, S. G. 2012. Primer3-New capabilities and interfaces. Nucleic Acids Res. 40:e115.

Valade, R., Cast, D., and Bert, F. 2015. Verticilliose du lin fibre, la prévention comme seule arme. Perspect. Agric. 424:30-32.

Vallad, G. E., Qin, Q.-M., Grube, R., Hayes, R. J., and Subbarao, K. V. 2006 Characterization of race-specific interactions among isolates of Verticillium dahliae pathogenic on lettuce. Phytopathology 96:1380-1387.

Vallad, G. E., and Subbarao, K. V. 2008. Colonization of Resistant and Susceptible Lettuce Cultivars by a Green Fluorescent Protein-Tagged Isolate of Verticillium dahliae. Phytopathology 98:871-885.

van Sumere, C. 1992. Retting of flax with special reference to enzyme-retting Pages 157-198 in: The Biology and Processing of Flax. H. Sharma and C. Van Sumere, eds. M Publications, Belfast, Northern Ireland.

Wang, B., Yang, X., Zeng, H., Liu, H., Zhou, T., Guo, L., and Qiu, D. 2012. The purification and characterization of a novel hypersensitive-like responseinducing elicitor from Verticillium dahliae that induces resistance responses in tobacco. Appl. Microbiol. Biotechnol. 93:191-201.

Wang, J., Cai, Y., Gou, J., Mao, Y., Xu, Y., Jiang, W., and Chen, X. 2004. VdNEP, an elicitor from Verticillium dahliae, induces cotton plant wilting. Appl. Environ. Microb. 70:4989-4995.

Wilhelm, S. 1955. Longevity of the Verticillium wilt fungus in the laboratory and field. Phytopathology 45:180-181.

Yadeta, K. A., and Thomma, B. P. H. J. 2013. The xylem as battleground for plan hosts and vascular wilt pathogens. Front. Plant Sci. 4:97.

Zelko, I., Lux, A., Sterckeman, T., Martinka, M., Kollárová, K., and Lišková, D. 2012. An easy method for cutting and fluorescent staining of thin roots. Ann. Bot. 110:475-478.

Zhang, W., Jiang, T., Cui, X., Qi, F., and Jian, G. 2012. Colonization in cotton plants by a green fluorescent protein labelled strain of Verticillium dahliae. Eur. J. Plant Pathol. 135:867-876.

Zhao, P., Zhao, Y., Jin, Y., Zhang, T., and Guo, H. 2014. Colonization process of Arabidopsis thaliana roots by a green fluorescent protein-tagged isolate of Verticillium dahliae. Protein Cell 5:94-98. 